\title{
Impacts of mule deer and horse grazing on transplanted shrubs for revegetation
}

\author{
DENNIS D. AUSTIN, PHILIP J. URNESS, AND SUSAN L. DURHAM
}

\begin{abstract}
Authors are research biologist and professor, Department of Range Science, and statistician, Department of Fisheries and Wildlife, Utah State University, Logan 84322-5230.
\end{abstract}

\section{Abstract}

Revegetation success on foothill ranges in northern Utah using big sagebrush (Artemisia tridentata Nutt. spp. wyomingensis Beetle and Young) and rubber rabbitbrush (Chrysothamnus nauseosus Britt. spp. albicaulis $\mathbf{H}$. and $C$.) was determined as influenced by winter mule deer browsing and spring horse grazing. Treatment areas of 0.1 ha with 3 replications included a protected control, use by deer only, use by horses only, use by deer and horses, and use by deer with horse grazing delayed for 3 years after seedling transplant. Results from the first 6 growing seasons following transplanting of seedlings showed grazing by horses only tripled the available, per-plant browse production of big sagebrush compared to protected plots, whereas browsing by deer only resulted in a $40 \%$ decrease in browse production. Seedling survival of big sagebrush differed between treatments during the first 3 growing seasons but was not affected by grazing after the third growing season. Rubber rabbitbrush was not affected by treatments.

Key Words: winter range, big sagebrush, rabbitbrush, northern Utah, reseeding

Records from the mid 1800 s of rangeland vegetation in northern Utah and southern Idaho valleys and foothill winter ranges indicate grasses dominated with very little browse (Hull and Hull 1974, Tisdale et al. 1969). With pioneer settlement and extensive grazing by livestock beginning in the late 1840 s, composition of the perennial grasslands was slowly shifted toward shrub-dominated communities (Harniss and Wright 1982, Reynolds 1960). The increase in shrubs, especially big sagebrush and several species of plants from the Rosaceae family, provided essential forage for survival of wintering mule deer (Odocoileus hemionus). Predictably, populations of mule deer continuously increased from the early $1900 \mathrm{~s}$ through the 1940s with regulated hunting (Hancock 1981).

However, because of decreased production of rangeland grasses and increased erosion as consequences from heavy livestock grazing, a gradual reduction in livestock numbers began about 1910 along foothill ranges. The increasing trend in forage production and habitat quality for mule deer was thereby reversed. In the absence of livestock grazing, grasses and perennial forbs reacquired their ecological advantage. This was particularly true where . shrubs were heavily grazed by deer in winter. As a result, vegetation on foothill winter ranges has slowly shifted toward grassdominated communities (Austin et al. 1986, Smith 1949).

The problem of limited big game winter range in Utah, particularly along the Wasatch Front and Cache Valley, became evident during the 1930s. Increasing numbers of big game, urbanization and dry-land farming along the narrow belt of foothill winter range, fire, and severe weather combined to cause depletion of native browse plants. This led to depredation of hay fields and

\footnotetext{
This paper is a contribution of Utah State Division of Wildlife Resources, Federal Aid Project W-105-R.

Manuscript accepted 28 Aug. 1993
}

orchards and malnutrition and starvation of mule deer (Austin and Urness 1987, Doman and Rasmussen 1944).

The difficulties associated with arid rangeland revegetation are many (Plummer et al. 1968) and success is unpredictable (Holmgren and Basile 1959). These problems are intensified where annual grasses and weeds are abundant because they increase competition for soil moisture (Guinta et al. 1975, Holmgren 1956, Price and Brotherson 1987). Livestock grazing of grasses and forbs in spring may benefit seeded browse species by reducing competition for soil moisture.

It is generally believed that protection from all grazers, domestic and wild, is preferred for the establishment of most browse species (Holmgren and Basile 1956). For example, Herbel (1983) indicated seedlings must be protected from grazing at least through the second growing season, and Monsen and Shaw (1983) recommended a protection period of 1 to 4 years. Protection from livestock grazing on most revegetation projects can be easily accomplished; however, exclusion of big game is almost never achieved due to the high costs of fencing. Substantial reduction of big game numbers is a second alternative but would rarely be acceptable to the public or management agencies. Consequently, revegetation projects are often faced with browsing of seeded shrubs by big game during winter and no livestock use of competing understory vegetation during the growing season.

The objective of this study was to determine the effects of grazing by horses in spring and early summer on revegetated winter range to balance winter browsing by deer. Thus, the question of whether livestock grazing can improve success of revegetation projects was investigated.

\section{Methods}

The foothill winter range on the east bench of Cache Valley between Green and Logan Canyons was selected for study. The location of the research pasture is at the base of the foothills just above residential housing on critical winter range. Previous studies from this location indicated a very productive winter range with numerous shrub species available in the 1930s (Doman and Rasmussen 1944), followed by a substantial reduction in shrubs by the late 1940s (Smith 1949). At the beginning of this study, the area was composed of annual grasses (e.g., Bromus tectorum L., Secale cereale L.), scattered forbs (e.g., Grindelia squarrosa (Pursh, Balsamorhiza sagittatta Pursh), and scattered dead skeletons of shrubs (Urness 1990).

A fenced pasture of 7.4 ha was constructed before transplanting seedlings. About 15,000, 1-year-old seedlings were hand-planted within contour-plowed furrows using a shrub planter in April, 1985. Distance between furrows was 1.5 to $3.0 \mathrm{~m}$ and spacings between plants within furrows were mostly 1.5 to $4.0 \mathrm{~m}$. Thus, shrub density was assumed to have no effects on seedling survival or productivity. Seedling species were big sagebrush (Artemisia 
tridentata Nutt. ssp. wyomingensis Beetle and Young) and rubber rabbitbrush (Chrysothamnus nauseosus Britt. ssp. albicaulis $\mathrm{H}$. and $C$.). Single species were transplanted within furrows, and species were randomly assigned among furrows.

A randomized block design, with 3 replications of 4 treatments and a control, was established after transplanting. Each of the 15 treatment areas measured $25 \times 40 \mathrm{~m}(0.1 \mathrm{ha})$. To decrease variability among treatments, individual furrows extended through all treatment areas within replications. Treatments included: (1) control: horses and deer excluded, (2) deer-only: horses excluded, (3) horse-only: deer excluded, (4) horse-delayed: horses excluded for the first 3 years following by 3 years of horse grazing, browsed every year by deer, (5) combined: used by horses and deer. Treatment areas within the pasture excluded horse and/or deer use from fall 1985 through fall 1990 using 1.2 and $2.4-\mathrm{m}$ high, woven-wire fences, as specified by treatment. Horses began grazing the 7.4-ha pasture including treatment areas 3 and 5 in spring 1986, and deer use of the pasture including treatment areas 2,4 , and 5 began during winter 1985-86.

Horse use of herbage within the treatment areas was determined from paired, $1-\mathrm{m}^{2}$, basketed and unprotected plots. Two plots were randomly located within each treatment area grazed by horses and were established each year before grazing began. Horse grazing occurred between about 1 May to 30 June. Following grazing, plots were hand-clipped at ground level. Herbage production on an air-dry weight basis and percent use were determined for each year as the mean over all plots.

Deer use of the entire pasture was determined from 60 permanent, $1-m^{2}$ plots located on a grid. The grid contained 4 parallel lines of 15 plots spaced at $10-15 \mathrm{~m}$ intervals, spanning the width of the pasture. Pellet groups were counted on plots and removed yearly in spring. To compute deer-days use/ ha, 13.0 pellet groups per deerday were used (Neff 1968). Deer use of the pasture was also indexed by evening (sunset) counts of deer. A minimum of 4 counts were made each year during midwinter (Dec.-Jan.). A third measure of deer overwinter use of the entire pasture was made each spring with a single ocular estimate of percent forage utilization of big sagebrush and rubber rabbitbrush. The 3 indices of deer use were collapsed over the entire pasture.

Ground cover was determined in fall 1986 and fall 1990, from 28 permanent, 9.3- $\mathrm{m}^{2}$ plots in each treatment area. Plots were located on a $7 \times 4$ equally spaced grid. Ground cover was not measured in fall 1985 because of the soil disturbance caused in revegetation. Ocular percent cover estimates of bare ground, litter, rock, annual plants, and perennial plants were made on each plot. The effects of treatment on the change in percent cover data from 1986 to 1990 for 5 response variables were evaluated separately by analyses of variance using blocks as replications. Differences between years were calculated as the value of 1990 minus the value in 1986 . A multivariate analysis was used to evaluate the 5 response variables for interaction main effects, and univariate analysis was used to test the 5 categories as independent variables. Pairwise comparisons among treatments were made using the Ryan-Einot-GabrielWelsch multiple range test at a 0.05 significance level (Welsch 1977). All analyses were performed using PROC GIM in SAS (SAS Institute, Inc. 1988).

Each fall all surviving seedlings were systematically counted by furrows within treatment areas to determine seedling density and survival. Our interest was in whether the number of seedlings followed the same trajectory through time for all treatments, i.e., whether a treatment by year interaction existed. We analyzed data for hig sagebrush and rubber rabbitbrush separately using an analysis of variance with repeated measures or as split plots in time by PROC GLM in SAS using blocks as replications. Differences among treatments between years were evaluated using single- degree-of-freedom contrasts.

Herbage production of all surviving shrubs in each treatment area was determined in fall 1990 by weight estimate (Pechanec and Pickford 1937). Weight of seed heads and vegetative stems and leaves was estimated separately for big sagebrush, whereas entire biomass was estimated for rubber rabbitbrush. Weight was converted to a dry weight basis using separate hand-collected, airdried samples. Seed heads and vegetative weight were summed to determine total dry weight for big sagebrush. Data for total dry weight of individual plants were evaluated by analysis of variance, using blocks as replications. Because the data set was unbalanced due to varying numbers of plants in each treatment area, we used the GLM procedure in SAS to compute approximate F-tests. Comparisons of main effect means were constructed as linear contrasts, and tests of significance were computed (Milliken and Johnson 1984).

\section{Horse and Deer Utilization}

\section{Results}

Herbage production was high in 1986 and 1990 , but low during the middle years as a result of drought (Table 1). Horse grazing reduced herbage biomass by $850 \mathrm{~kg} \mathrm{ha}^{-1}$ year $^{-1}$ over 5 years at a grazing level of about $50 \%$.

Table 1. Herbage production and utilization within 0.1-ha treatment areas. Date are sample means over all treatment areas grazed by horses.

\begin{tabular}{lcccccc}
\hline \hline & \multirow{2}{*}{$\begin{array}{c}\text { Number of } \\
\text { horses }\end{array}$} & \multicolumn{2}{c}{ Production $\left(\mathrm{g} \mathrm{m}^{-2}\right)$} & & \multicolumn{2}{c}{ Utilization (\%) } \\
\cline { 3 - 4 } \cline { 6 - 7 } & & mean & $\mathrm{SE}^{1}$ & & mean & $\mathrm{SE}$ \\
\hline 1986 & 8 & 229 & 81 & & 50 & 25 \\
1987 & 5 & 102 & 67 & & 35 & 38 \\
1988 & 3 & 150 & 43 & & 34 & 22 \\
1989 & 5 & 129 & 45 & & 71 & 13 \\
1990 & 6 & 241 & 80 & & 58 & 17 \\
Mean & 5 & 170 & & & 50 & \\
\hline
\end{tabular}

ISE = Standard Error

The number of pellet-group plots was probably too few to detect changes in deer populations. The 5-year mean indicated a use level of 56 deer-days/ha (Table 2). The number of deer counted per observation on the pasture during December and January indicated a similar level of use at $\mathbf{6 4}$ deer-days/ha. Because of its limited availability, utilization of big sagebrush remained high all years. However, the subspecies of rubber rabbitbrush was low in palatability and received little use.

\section{Ground Cover}

The multivariate analysis revealed no evidence of an overall treatment effect $(P=0.31)$. No treatment effect was evident for percent cover of rock ( $P=0.07)$, litter $(P=0.25)$, or perennial plants $(P=0.16)$ (Table 3). However, the changes in bare ground between years were different among treatments $(P<0.01)$ with the control different from the horse-delayed, horse-only, and combined treatments. The changes in annual plant cover between years were also different among treatments $(P=0.02)$, but the control was not different from any other treatment. However, the deer-only treatment was different from the horse-delayed and combined treatments.

\section{Survival of Seedlings and Browse Production}

The number of surviving shrubs of big sagebrush decreased on all treatments between 1985 and 1987, and between 1987 and 1990 (Table 4). The interaction between treatment and year factors was significant $(P=0.02)$. The decline in mean number of surviving shrubs between 1985 and 1987 differed by treatment $(P=0.008)$, but the decline between 1985 and 1987 was not different for any treatment $(P=0.47)$. Mortality of sagebrush seedlings between 1985 and 1987 was higher in the combined treatment than in any other 
Table 2. Pellet groups, counts, and browse use indices of mule deer.

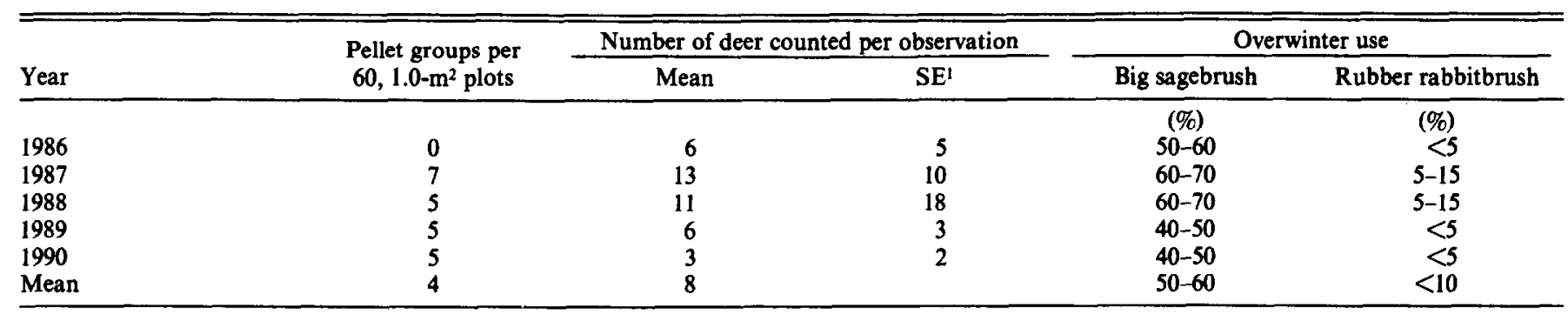

ISE $=$ Standard Error

Table 3. Ground cover in 1986 and in 1990 for grazing treatments in Cache Valley, Utah'.

\begin{tabular}{lcccccc}
\hline & & Bare & & & \multicolumn{2}{c}{ Plants } \\
\cline { 6 - 7 } Treatment & Year & ground & Litter & Rock & Annuals Perennials \\
\hline \multirow{3}{*}{ Control } & 1986 & $26 \mathrm{a}^{2}$ & $(\%)$ & $(\%)$ & $(\%)$ & $(\%)$ \\
& 1990 & 8 & 25 & 17 & $30 \mathrm{ab}$ & 1 \\
Delayed & 1986 & $34 \mathrm{~b}$ & 26 & 11 & $28 \mathrm{~b}$ & 2 \\
Horse & 1990 & 32 & 30 & 11 & 20 & 7 \\
Horse-only & 1986 & $32 \mathrm{~b}$ & 29 & 10 & $27 \mathrm{ab}$ & 1 \\
& 1990 & 33 & 24 & 10 & 25 & 8 \\
Deer-only & 1986 & $32 \mathrm{ab}$ & 28 & 10 & $30 \mathrm{a}$ & 1 \\
& 1990 & 7 & 33 & 4 & 52 & 4 \\
Combined & 1986 & $31 \mathrm{~b}$ & 25 & 19 & $24 \mathrm{~b}$ & 1 \\
& 1990 & 35 & 24 & 20 & 15 & 6 \\
Mean & 1986 & 31 & 26 & 13 & 28 & 1 \\
& 1990 & 23 & 30 & 11 & 30 & 6 \\
\hline
\end{tabular}

Data collected from 28 circular $1.0 \mathrm{~m}^{2}$ plots/replication/treatment.

2 Within a column, changes in cover between years within a treatment are not differen from other treatments with the same lower case letter at $P<0.05$.

treatment ( $P<0.10$ ); no other significant differences were observed.

Survival rates for rubber rabbitbrush were high on all treatments (Table 4). Treatment and years were not significant $(P>0.60)$, and the interaction between treatment and year factors was also not significant $(P=0.30)$.

\section{Table 4. Surviving seedling density and production per plant in the fall following establishment of big sagebrush and rabhitbrush seedlings in spring 1985.}

\begin{tabular}{lcccc}
\hline & \multicolumn{3}{c}{ Seedling density } & \multicolumn{1}{c}{ Production } \\
\cline { 2 - 4 } Treatment & 1985 & 1987 & 1990 & 1990 \\
\hline Big sagebrush & $-\ldots \ldots$ & plants $0.1 \mathrm{ha}^{-1}$ & $\ldots \ldots$ & $\left(\mathrm{g} \mathrm{plant}^{-1}\right)$ \\
Control & $367 \mathrm{a}^{1}$ & $305 \mathrm{~b}$ & $288 \mathrm{c}$ & $80 \mathrm{bc}^{2}$ \\
Horse-delayed & $428 \mathrm{a}$ & $353 \mathrm{~b}$ & $315 \mathrm{c}$ & $77 \mathrm{bc}$ \\
Horse-only & $435 \mathrm{a}$ & $350 \mathrm{~b}$ & $337 \mathrm{c}$ & $146 \mathrm{a}$ \\
Deer-only & $323 \mathrm{a}$ & $216 \mathrm{~b}$ & $192 \mathrm{c}$ & $48 \mathrm{c}$ \\
Combined & $409 \mathrm{a}$ & $247 \mathrm{~b}$ & $235 \mathrm{c}$ & $90 \mathrm{~b}$ \\
Mean & 392 & 294 & 273 & 88 \\
Rubber rabbitbrush & & & & \\
Control & 271 & 227 & 244 & 185 \\
Horse-delayed & 319 & 316 & 353 & 268 \\
Horse-only & 248 & 222 & 230 & 303 \\
Deer-only & 306 & 318 & 308 & 281 \\
Combined & 188 & 167 & 182 & 259 \\
Mean & 266 & 250 & 263 & 259 \\
\hline
\end{tabular}

'Number of surviving seedlings within a row with a common lower case letter are not significant at $P<0.05$.

${ }^{2}$ Means of production within a column and species with a common lower case letter are not significant at $P<0.05$.

${ }^{3}$ No interaction between treatment and years were detected $(P=0.30)$, and neither treatment nor year effects were significant $(P>0.60)$.
The effect of treatment on forage production of big sagebrush (Table 4) was significant $(P=0.01)$. Production of big sagebrush was highest for the horse-only treatment, and greater than that for the second highest treatment of combined use $(P=0.01)$ and for all other treatments. Production for combined use was not different from either the control $(P=0.56)$ or the horse-delayed $(P=0.44)$ treatments, but was different from the lowest production deer-only treatment $(P=0.03)$. Production on the deer-only treatment was lower than production on the control $(P=0.08)$ and horse-delayed treatments $(P=0.11)$.

No treatment effects (Table 4) on forage production of rubber rabbitbrush were found $(P=0.60)$.

\section{Discussion}

Livestock grazing is often necessary to maintain shrubs on winter ranges (Price and Brotherson 1987, Reiner and Urness, 1982, Smith 1949), can improve big game winter ranges (Jensen et al. 1972, Riggs and Urness 1989, Smith and Doell 1968, Urness 1981) and can result in increased grazing capacity for both livestock and big game (Frisina and Morin 1991). However, the potentially beneficial effects of using livestock grazing to shift competitive relationships between seeded shrubs and less desirable annual grasses on revegetation sites have not been fully elucidated.

Owens and Norton (1990), in other investigations of the livestock grazing-shrub revegetation interaction, found survival of basin big sagebrush (Artemisia tridentata Nutt. spp. tridentata Beetle) seedlings was higher under short duration than season-long grazing. However, seedling mortality of basin big sagebrush at the end of the first growing season did not differ between grazed and ungrazed pastures (Owens and Norton 1992). McConville (1986) reported that cattle grazing in spring on crested wheatgrass (Agropyron cristatum $\mathrm{L}$.) pastures enhanced the establishment of transplanted fourwing saltbush (Atriplex canescens Pursh) and antelope bitterbrush (Purshia tridentata Pursh), but had no effect on transplanted mountain big sagebrush (Artemisia tridentata Nutt. spp. vaseyana Beetle) or 1-year-old seedlings of antelope bitterbrush. Monsen and Shaw (1983) reported grazing by cattle on seeded antelope bitterbrush reduced survival by $36 \%$ over protected areas. However, bitterbrush plants were heavily grazed by cattle.

In this study, horse grazing in May and June removed about 50\% of the herbage biomass. Deer used slightly over half of the forage from big sagebrush yearly. At these levels of livestock and big game use, which are common on Utah ranges (Austin et al. 1983), the effects of horse grazing increased winter browse of big sagebrush for deer on revegetated rangeland by apparently shifting the growth advantage in favor of big sagebrush. Similar results were reported for bitterbrush (Reiner and Urness 1982). However, we observed no effect on rubber rabbitbrush in our study.

This study indicates use by deer and horses of revegetated rangelands containing seedlings of big sagebrush less than 3 years old 
may reduce seedling survival. However, our results are inconclusive on this point. Conversely, when plants reached 4 to 6 years of age, use had no effect on survival.

For decades the number of livestock allowed to graze on many federally controlled deer winter ranges in Utah has been substantially decreased or eliminated, along with a corresponding decrease in shrub density and deer carrying capacity (Austin et al. 1986). From the viewpoint of deer browsing on winter ranges, our data indicate moderate levels of livestock grazing in spring are desirable.

Our study suggests a simple management plan for revegetated areas which have the primary goal of maximizing browse forage for wintering big game. Per-plant production of big sagebrush will be maximized by horse grazing and deer exclusion under conditions similar to those in our study. During the first 3 years following planting, deer numbers should be reduced, or the seeded area should be protected from winter grazing. Livestock grazing may be employed in spring to reduce fire potential and to utilize available forage. After 3 years, livestock grazing, preferably with horses because of their high preference for grasses (Reiner and Urness 1982), should be applied yearly during spring to shift the growth advantage from understory vegetation to big sagebrush and other important browse species.

\section{Literature Cited}

Austin, D.D., and P.J. Urness. 1987. Consumption of fresh alfalfa hay by mule deer and elk. Great Basin Natur. 47:100-102.

Austin, D.D., P.J. Urness, and L.C. Fierro. 1983. Spring livestock grazing affects crested wheatgrass regrowth and winter use by mule deer. $J$. Range Manage. 36:589-593.

Austin, D.D., P.J. Urness, and R.A. Riggs. 1986. Vegetal change in the absence of livestock grazing, mountain brush zone, Utah. J. Range Manage. 39:514-517.

Doman, E.R. and D.I. Rasmussen. 1944. Supplemental winter feeding of mule deer in northern Utah. J. Wildl. Manage. 8:317-338.

Frisina, M.R. and F.G. Morin. 1991. Grazing private and public land to improve the Fleecer elk winter range. Rangelands 13:291-294.

Guinta, B.C., D.R. Christensen, and S.B. Monson. 1975. Interseeding shrubs in cheatgrass with a browse seeder-scalper. J. Range Manage. 28:398-402.

Hancock, N.V. 1981. Mule deer management in Utah-past and present. p. 2-27. In: F.G. Lindzey (ed.), Proc. Utah. Mule Deer Workshop. Utah Coop. Wildl. Res. Unit, Utah State Univ., Logan.

Harniss, R.O., and H.A. Wright. 1982. Summer grazing of sagebrush-grass range by sheep. J. Range Manage. 35:13-17.

Herbel, C.H. 1983. Principles of intensive range improvements. J. Range Manage. 36:140-144.

Holmgren, R.C. 1956. Competition between annuals and young bitterbrush (Purshia tridentata) in Idaho. Ecology 37:370-377.

Holmgren, R.C., and J.V. Basile. 1956. Range revegetation on the Payette. Idaho Wildl. Rev. 9:10-13.
Holmgren, R.C., and J.V. Basile. 1959. Improving southern Idaho deer winter ranges by artificial revegetation. Idaho Dep. Fish and Game. Wildl. Bull. 3.

Hull, A.C., and M.K. Hull. 1974. Presettlement vegetation of Cache Valley, Utah and Idaho. J. Range Manage. 27:27-29.

Jensen, C.H., A.D. Smith, G.W. Scotter. 1972. Guidelines for grazing sheep on rangelands used by big game in winter. J. Range Manage. 32:214-216.

McConville, L.M. 1986. Effect of spring livestock grazing by cattle and growth and survival of shrub seedlings interplanted in crested wheatgrass. M.S. Thesis. Utah State Univ., Logan.

Milliken, G.A., and D.E. Johnson. 1984. Analysis of messy data. Vol. 1. Designed experiments. Lifetime Learning Pub., Belmont, Calif.

Monsen, S.B., and N.L. Shaw. 1983. Seeding antelope bitterbrush with grasses on south-central Idaho rangelands-A 39-year response. USDA Forest Serv. Gen. Tech. Rep. INT-52. Ogden, Ut.

Neff, D.J. 1968. The pellet-group count technique for big game trend, census, and distributions: a review. J. Wildl. Manage. 32:597-614.

Owens, M.K., and B.E. Norton. 1990. Survival of juvenile basin big sagebrush under different grazing regimes. J. Range Manage. 43:132-135.

Owens, M.K., and B.E. Norton. 1992. Interactions of grazing and plant protection on basin big sagebrush (Artemisia tridentata spp. tridentata) seedling survival. J. Range Manage. 45:257-262.

Pechanec, J.F., and G.D. Pickford. 1937. A weight estimate method for determination of range or pasture production. J. Amer. Soc. Agron. 29:894-904.

Plummer, A.P., D.R. Christensen, and S.B. Monsen. 1968. Restoring big game range in Utah. Utah State Div. of Fish and Game. Pub. 68-3.

Price, K.P., and J.D. Brotherson. 1987. Habitat and community relationships of cliffrose (Cowania mexicana var. stansburiana) in central Utah. Great Basin Natur. 47:132-151.

Reiner, R.I., and P.J. Urness. 1982. Effect of grazing horses managed as manipulators of big game winter range. J. Range Manage. 35:567-571.

Reynolds, T.A. 1960. The mule deer. Utah State Dep. of Fish and Game Pub. 60-4.

Riggs, R.A., and P.J. Urness. 1989. Effects of goat browsing on Gambel oak communities in northern Utah. J. Range Manage. 42:354-360.

SAS Institute, Inc. 1988. SAS / STAT ${ }^{\text {TM }}$ User's guide, Release 6.03 Ed. Cary, N.C.

Smith, A.D. 1949. Effects of mucle deer and livestock upon a foothill range in northern Utah. J. Wildl. Manage. 12:21-23.

Smith, A.D., and D.D. Doell. 1968. Guides to allocating forage between cattle and big game on winter ranges. Utah State Div. Fish and Game Pub. 68-11.

Tisdale, E.W., M. Hironaka, and M.A. Fosberg. 1969. The sagebrush region in Idaho-a problem in range resource management. Idaho Agr. Exp. Sta. Bull. 512.

Urness, P.J. 1981. Livestock as tools for managing big game winter range in the Intermountain West, p. 20-31. In: J.M. Peck and P.D. Dalke (eds.), Proc. 10. Wildlife-livestock Relationship Symp. Forest, Wildlife and Range Exp. Sta. Moscow, Ida.

Urness, P.J. 1990. Livestock as manipulators of mule deer winter habitats in northern Utah. USDA Forest Serv. Gen. Tech. Rep. RM-194. Fort Collins, Colo.

Welch, R.E. 1977. Stepwise multiple comparison procedures. J. Amer. Stat. Assoc. 72:359. 